\title{
Validacija slovenske oblike Kaufmanovega vprašalnika ustvarjalnih področij
}

\author{
Lina Faletič ${ }^{*}$ in Andreja Avsec ${ }^{2}$ \\ ${ }^{1}$ Osnovna šola Košana \\ ${ }^{2}$ Oddelek za psihologijo, Filozofska fakulteta, Univerza v Ljubljani
}

\begin{abstract}
Povzetek: Namen naše raziskave je bil sistematično raziskati merske značilnosti slovenskega prevoda Kaufmanovega vprašalnika ustvarjalnih področij K-DOCS, ki preko samoocenjevanja meri stopnjo ustvarjalnega vedenja na osebnem/medosebnem, študijskem, izvedbenem, tehničnem/znanstvenem in umetniškem področju. Udeleženci $(N=319)$ so izpolnili omenjeni vprašalnik in Vprašalnik velikih pet BFI-K. Konfirmatorna faktorska analiza vprašalnika K-DOCS je pokazala, da se petfaktorski model dobro prilega podatkom, torej je razvrstitev ustvarjalnega vedenja na pet področij, kot jih je predlagal avtor vprašalnika, ustrezna. Povezanost med petimi področji ustvarjalnosti ter velikimi petimi faktorji osebnosti se je ujemala s pričakovanji, saj se je z vsemi področji ustvarjalnosti, razen s tehničnim/znanstvenim, najbolj povezovala odprtost za izkušnje. Ravno tako so bili rezultati razlik med spoloma skladni s pričakovanji, saj so moški poročali o višji ustvarjalnosti na tehničnem/znanstvenem področju, ženske pa na umetniškem področju. Slovenski prevod Kaufmanovega vprašalnika ustvarjalnih področij se je izkazal kot zanesljiv in konstruktno veljaven inštrument za merjenje posameznikove ocene lastne ustvarjalnosti na petih področjih vsakodnevnega življenja.
\end{abstract}

Ključne besede: Kaufmanove lestvice ustvarjalnih področij, validacija, faktorska struktura, osebnostne lastnosti, razlike med spoloma

\section{Validation of the Slovene form of Kaufman Domains of Creativity Scale}

\author{
Lina Faletič ${ }^{*}$ and Andreja Avsec ${ }^{2}$ \\ ${ }^{1}$ Primary school Košana, Slovenia \\ ${ }^{2}$ Department of Psychology, Faculty of Arts, University of Ljubljana, Slovenia
}

\begin{abstract}
The aim of our study was to systematically investigate the metric characteristics of the Slovenian translation of the Kaufman Domains of Creativity Scale (K-DOCS), a self-report questionnaire for measuring self/everyday, scholarly, performance, mechanical/ scientific and artistic creativity. The participants $(N=319)$ filled in the mentioned questionnaire and the Big Five Questionnaire BFI-K. Confirmatory factor analysis of the K-DOCS questionnaire showed adequate fit of the originally proposed five-factor model to the data. The correlation matrix of the five areas of creativity and the big five factors of personality matched our expectations as openness to experience had maximum correlations with all areas of creativity, with the exception of mechanical/scientific creativity. Gender differences were also consistent with our expectations, as men reported higher mechanical/scientific creativity, and women higher artistic creativity. The Slovenian translation of the Kaufman Domains of Creativity Scale (K-DOCS) has therefore proved to be a reliable and valid instrument for measuring an individual's self-assessed creativity in five domains.
\end{abstract}

Keywords: Kaufman Domains of Creativity Scale (K-DOCS), validation, factor structure, personality traits, gender differences

\footnotetext{
*Naslov/Address: Lina Faletič, Osnovna šola Košana, Dolnja Košana 61, 6256 Košana, e-mail: lina.faletic@gmail.com

Članek je licenciran pod pogoji Creative Commons Attribution 4.0 International licence. (CC-BY licenca).

The article is licensed under a Creative Commons Attribution 4.0 International License (CC-BY license).
} 
Ustvarjalnost je postala pomembna raziskovalna tema, saj spodbuja inovativnost in je ključnega pomena za uspeh in napredek posameznika in družbe kot celote (Stierand, Dörfler in MacBryde, 2014). Inovativne ideje, ki jih razvijejo posamezniki $\mathrm{v}$ organizacijah, se neposredno povezujejo $\mathrm{z}$ višjo plačo, napredovanjem in zadovoljstvom s kariero, ter uspešnostjo celotne organizacije. Poleg tega se ustvarjalnost povezuje $\mathrm{z}$ boljšim telesnim zdravjem ter višjim splošnim blagostanjem in delovanjem posameznika (Carmeli, McKay in Kaufman, 2013). Kljub razmahu raziskovanja pa se področje ustvarjalnosti še vedno spopada $\mathrm{z}$ »začetniškimi« problemi kot je npr. opredelitev in merjenje ustvarjalnosti.

Opredelitve ustvarjalnosti se $\mathrm{v}$ večji meri prekrivajo (Abraham in Windmann, 2007; Allen in Thomas, 2011; Csikszentmihalyi, 1997); standardna opredelitev ustvarjalnosti vključuje vidik izvirnosti oz. originalnosti in vidik učinkovitosti (Runco in Jaeger, 2012), pri čemer se ta učinkovitost lahko nanaša na uporabnost, ustreznost, vrednost, primernost ... Silvia (2018) sicer problematizira to standardno opredelitev, saj je smiselna samo v primeru, da zelo raztegnemo pomen njenih posameznih komponent, predvsem kaj vse lahko pomeni učinkovitost. Pri opredeljevanju učinkovitosti in originalnosti pa je treba opozoriti tudi na pomen širšega socialno-kulturnega okolja (Glăveanu, 2019; Silvia, 2018), ki določa, kaj v določenem času in prostoru pomeni biti izviren in učinkovit.

Kompleksnost področja ustvarjalnosti pa se ne odraža le pri problemu njene opredelitve, pač pa tudi pri njenem merjenju, saj so možnosti merjenja zelo raznolike. Raziskovalci ustvarjalnosti so se primarno osredotočili na tri vidike merjenja, in sicer na merjenje ustvarjalnega mišljenja, ki so ga večinoma povezovali $\mathrm{z}$ divergentnim mišljenjem, na ustvarjalne dosežke in izdelke ter na samoocene pogostosti ali stopnje ustvarjalnega vedenja (Silvia, Wigert, Reiter-Palmon in Kaufman, 2012; Miller, 2014). Guilford (1950) je bil eden prvih raziskovalcev, ki je poskušal oblikovati sistematično teorijo ustvarjalnosti ter jo tudi eksperimentalno preveriti. Ustvarjalnost je v veliki meri enačil $\mathrm{z}$ divergentnim mišljenjem in jo primarno definiral s fluentnostjo, fleksibilnostjo in originalnostjo oblikovanih idej, sekundarno pa tudi z njihovo elaboracijo (dodelanostjo) in redefinicijo (Abraham in Windmann, 2007). Na podlagi njegovega dela je Torrance oblikoval naloge ustvarjalnega mišljenja (Dollinger, Urban in James, 2004), pri katerih udeleženci verbalno ali preko risb navajajo ideje za določen problem (npr. na kakšen način lahko uporabimo kartonasto škatlo). Ta način merjenja ustvarjalnosti je vsebinsko bogat, dobro napoveduje posameznikove ustvarjalne dosežke (Jeon, Moon in French, 2011), vendar je omejen na potencial za ustvarjalno vedenje, saj ne preverja, ali ima oseba tudi dejanske ustvarjalne izdelke (Piffer, 2012).

$\mathrm{Za}$ ocenjevanje stopnje ustvarjalnosti posameznih izdelkov se najpogosteje uporablja tehnika konsenzualnega ocenjevanja, ko usposobljeni strokovnjaki na podlagi lastnih kriterijev ocenjujejo izvirnost in ustreznost izdelkov (Kaufman in Baer, 2012). Ocenjevanje izdelkov predstavlja najbolj neposreden način ocenjevanja posameznikove ustvarjalnosti, je pa potrebno poudariti, da je praktično nemogoče primerjati med seboj izdelke na različnih področjih ustvarjanja (pesem s kratko prozo ali pesem $\mathrm{z}$ računalniškim programom), kar pomeni, da moramo pri raziskavah izhajati iz tipa ustvarjalnega izdelka.

Najenostavnejši za uporabo so vprašalniki, ki merijo ustvarjalno vedenje preko samoocenjevanja. $\mathrm{V}$ ta namen posamezniki sami ocenijo, kako ustvarjalni so na splošno ali kako ustvarjalni so njihovi produkti. Na ravni vsakodnevne ustvarjalnosti se najpogosteje uporabljajo samoocenjevalni vprašalniki, kjer posamezniki poročajo o pogostosti ustvarjalnega vedenja (npr. kako pogosto skuhajo nekaj novega, si izmislijo šalo ali napišejo sms v rimah) oziroma kako ustvarjalno se jim zdi njihovo določeno vedenje (kako dobre šale si izmislijo) glede na referenčno skupino (Carson, Peterson in Higgins, 2005). Problem samoocenjevanja je vsekakor podajanje socialno zaželenih odgovorov, saj ustvarjalno vedenje družba zelo ceni. Vseeno raziskave kažejo, da je porazdelitev dosežkov na samoocenjevalnih lestvicah ustvarjalnosti pogosto levo asimetrična, kar pomeni, da nekateri udeleženci nimajo težav poročati o manjši količini ustvarjalnih dosežkov (Silvia, idr., 2012).

Napovedno veljavnost samoocenjevanja ustvarjalnega vedenja lahko preverimo $\mathrm{s}$ povezavami $\mathrm{z}$ ustvarjalnimi dosežki. Samoocene ustvarjalnega vedenja na posameznih področjih ustvarjanja dobro napovedujejo posameznikove ustvarjalne dosežke (npr. Silvia idr., 2012), po drugi strani pa sta Pretz in McCollum (2014) ugotavila, da je samoocena boljši napovednik ustvarjalnega dosežka na ravnokar opravljeni nalogi kot splošna samoocena ustvarjalnosti. Posamezniki se torej dobro zavedajo, ali je neko njihovo konkretno vedenje ustvarjalno ali ne, problem pa očitno predstavljajo bolj posplošene sodbe o lastni ustvarjalnosti. V nadaljevanju prispevka se bomo osredotočili na samoocene na specifičnih področjih ustvarjalnosti, saj želimo sistematično raziskati merske značilnosti slovenskega prevoda Kaufmanovega vprašalnika ustvarjalnih področij (Kaufman, 2012).

Med raziskovalci sicer ni splošnega konsenza, ali je sploh smiselno meriti ustvarjalnost na posameznih področjih ali je bolje govoriti o ustvarjalnosti na splošno. Nekateri avtorji izhajajo iz splošnega faktorja ustvarjalnosti in svoje prepričanje utemeljujejo z raziskavami, ki ugotavljajo, da dosežek posameznika na testu divergentnega mišljenja $\mathrm{v}$ osnovni šoli napoveduje statistično pomemben delež variance ustvarjalnih dosežkov posameznika v odraslosti, ne glede na področje ustvarjalnosti (Jeon idr. 2011). Po drugi strani pa zagovorniki večfaktorskega modela $\mathrm{v}$ ospredje postavljajo nizko povezanost med dosežki na testu divergentnega mišljenja in ustvarjalnimi dosežki na specifičnih področjih ter različno povezanost samoocene splošne ustvarjalnosti s samooceno ustvarjalnosti na različnih področjih (Jeon idr. 2011). Avtorji samoocenjevalnih vprašalnikov ustvarjalnega vedenja večinoma izhajajo iz večfaktorskega modela in vanje vključujejo različna področja ustvarjalnosti.

Vprašalnik ustvarjalnih dosežkov CAQ (Creativity AchivementQuestionnaire; Carsonidr., 2005) meriustvarjalne dosežke (npr. ali je nek izdelek bil javno predstavljen, ali je posameznik lahko zaslužil z njim, ali je prepoznan na nacionalni ravni) na desetih področjih. Avtorji so na podlagi faktorske analize področja združili v dve dimenziji, in sicer gledališče, pisanje, humor, glasba, vizualna umetnost in 
ples so sestavljali umetniško ustvarjalnost, izumi, znanost in kulinarika pa znanstveno ustvarjalnost. Arhitektura se ni vključila $v$ nobeno od dimenzij. Z. Ivcevic in Mayer (2009) sta oblikovala vprašalnik pogostosti vključevanja $v$ ustvarjalno vedenje $\mathrm{z}$ naslednjimi področji ustvarjalnosti: ustvarjalni življenjski stil, ki je vključeval ustvarjalno prikazovanje sebe, medosebno ustvarjalnost, izdelovanje, uporabo medijev $\mathrm{v}$ namene izobraževanja na posameznem ustvarjalnem področju in kulturno udejstvovanje, umetniško ustvarjalnost, ki je vključevala glasbo, ples, gledališče, vizualno umetnost in pisanje, ter intelektualno ustvarjalnost, ki je vključevala tehnologijo, znanost in akademsko usmerjenost. Vprašalnik ustvarjalnosti CSDD (Creativity Scale for Diverse Domains; Kaufman in Bear, 2004) meri samooceno stopnje ustvarjalnosti na devetih področjih (za vsako področje samo ena postavka), združenih v tri faktorje, in sicer: ustvarjalnost $\mathrm{v}$ medosebnih odnosih (medosebni odnosi, medosebna komunikacija, reševanje osebnih problemov, pisanje), neposredna ustvarjalnost (umetnost, obrt, telesna ustvarjalnost) in znanstvena ustvarjalnost (ustvarjalnost na področju matematike in naravoslovja). Vprašalnik ustvarjalnih področij CDQ (Creativity Domain Questtionnaire; Kaufman, 2006; Kaufman idr., 2010) po drugi strani vključuje 56 različnih ustvarjalnih vedenj, združenih v sedem faktorjev: verbalna umetnost, vizualna umetnost, podjetništvo, medosebna ustvarjalnost, matematika/ znanost, izvedbena ustvarjalnost in reševanje problemov. Pri skrajšani obliki vprašalnika so dobili le štiri faktorje, in sicer matematika/znanost, gledališče, medosebna ustvarjalnost in umetnost (Kaufman idr., 2010; Silvia idr., 2012).

Na podlagi vseh naštetih raziskav je Kaufman leta 2012 oblikoval Kaufmanov vprašalnik ustvarjalnih področji KDOCS (Kaufman Domains of Creativity Scale), s katerim je posameznike na 94 postavkah spraševal, kako bi se na lestvici od 1 (bistveno manj ustvarjalen) do 5 (bistveno bolj ustvarjalen) ocenili $\mathrm{v}$ primerjavi $\mathrm{z}$ njihovimi vrstniki pri posameznih aktivnostih (npr. pisanje bloga). Postavke je oblikoval tako, da je preoblikoval postavke vključene $\mathrm{v}$ Vprašalniku ustvarjalnih področij iz ocene situacije $v$ opis vedenja, pomagal pa si je tudi z vprašalniki Z. Ivcevic in Mayerja (2009) ter Carsona s sodelavci (2005). Z analizo glavnih komponent je izločil pet komponent ustvarjalnosti in sicer osebno/medosebno, študijsko, izvedbeno, tehnično/ znanstveno in umetniško ustvarjalnost. Število postavk je zmanjšal s 94 na 50, pri čemer je izločil postavke, ki niso bile visoko nasičene $\mathrm{z}$ nobeno komponento $(<0,40)$, in tiste, ki so bile približno enako nasičene $\mathrm{z}$ več faktorji. Petfaktorsko strukturo vprašalnika so potrdili tudi pri mednarodnem vzorcu udeležencev, ki so vprašalnik izpolnjevali v angleškem jeziku in na vzorcu poljskih udeležencev (McKay, Karwowski in Kaufman, 2017).

Konstruktno veljavnost vprašalnika K-DOCS so raziskovalci preverili $\mathrm{s}$ pomočjo korelacij med dobljenimi lestvicami ter petimi velikimi faktorji osebnosti (McKay idr., 2017). Smiselno je namreč predpostavljati, da lahko določena konstelacija osebnostnih lastnosti olajša pojavitev ustvarjalnega vedenja (Feist, 2010), pri čemer je pomembno izpostaviti, da se ustvarjalnost ne povezuje le z osebnostjo, temvečtudizinteligentnostjo(Csikszentmihalyi, 1997; Carson, idr., 2005; Kim, 2005) predznanjem (Jeon idr., 2011), čustvi
(Ivcevic, Brackett in Mayer, 2007; Fürst, Ghisletta in Lubart, 2012; Conner in Silvia, 2015) ter motivacijo in interesom za področje (Jeon idr., 2011; Zhang in Sternberg, 2011; Sternberg, 2012). Različne raziskave so dokazale povezanost med ustvarjalnostjo ter osebnostjo in inteligentnostjo, pri čemer je večina ugotovila, da ima osebnost višjo napovedno vrednost pri napovedovanju ustvarjalnosti kot inteligentnost (Grosul in Feist, 2014).

Če se osredotočimo na osebnost, ki jo bomo kot kriterijsko spremenljivko uporabili tudi $\mathrm{v}$ naši raziskavi, se zdijo najbolj relevantne tiste osebnostne lastnosti, ki se nanašajo na medosebne razlike $\mathrm{v}$ načinu predelovanja informacij, reševanja problemov in odzivanja na nove situacije. Gre za posameznikovo sposobnost in nagnjenost $\mathrm{k}$ iskanju, zaznavanju, obdelovanju, uporabi in vrednotenju kompleksnih vzorcev informacij, tako senzornih kot abstraktnih, kar zajema osebnostna lastnost odprtost (DeYoung, Quilty, Peterson in Gray, 2014). Raziskave kažejo, da je od petih velikih faktorjev osebnosti odprtost/intelekt najpomembnejši napovednik ustvarjalnosti (povprečna velikost učinka $d=$ 0,71; Ma, 2009).

Drugi sklop osebnostnih lastnosti, ki olajšujejo prag za pojavitev ustvarjalnega vedenja, se nanaša na medosebne odnose. Za ustvarjalne posameznike naj bi bila značilna gotovost vase, neodvisnost, dominantnost, introvertnost, tudi hladnost in sovražnost $\mathrm{v}$ medosebnih odnosih (Feist in Barron, 2003), vendar so rezultati metaanalize (Ma, 2009) pokazali zelo šibko pozitivno povezanost ustvarjalnosti s sprejemljivostjo (povprečna velikost učinka $d=0,15$ ), kar pomeni, da večina bolj ustvarjalnih posameznikov vseeno ni nesprejemljivih. Metaanaliza je pokazala tudi višjo povezanost ustvarjalnosti z ekstravertnostjo (povprečna velikost učinka $d=0,30)$. Vestnost je tista dimenzija velikih petih, ki v največji meri vključuje motivacijo za dosežke, vendar metaanaliza (Ma, 2009) kaže nizko pozitivno povezanost ustvarjalnosti $\mathrm{z}$ vestnostjo (povprečna velikost učinka $d=$ 0,23 ), verjetno zato, ker se ne nanaša na notranjo motivacijo, ki je tako zelo pomembna za ustvarjalnost. Nevroticizem je najbolj nekonsistentno povezan $\mathrm{z}$ ustvarjalnostjo, verjetno zaradi različnega odnosa glede na področje ustvarjalnosti, saj naj bi bil negativno povezan $\mathrm{z}$ znanstveno ustvarjalnostjo in pozitivno z umetniško ustvarjalnostjo (Ma, 2009).

Eden od indikatorjev veljavnosti Kaufmanovega vprašalnika ustvarjalnih področij so lahko tudi razlike med spoloma, saj na bi vprašalnik ustrezno, torej skladno $\mathrm{s}$ pričakovanji, razločeval med spoloma. Predhodne raziskave na splošno ugotavljajo, da ženske poročajo o višji ustvarjalnosti na medosebnih, osebnih in umetniških področjih, moški pa na znanstvenih in tehničnih. Z. Ivcevic in Mayer (2009) sta tako ugotovila, da so ženske poročale o višji ustvarjalnosti na področju življenjskega stila, moški pa na področju intelektualne ustvarjalnosti. Do podobnih zaključkov je prišel Kaufman s sodelavci (2010), ki je ugotovil, da so moški poročali o višji stopnji ustvarjalnosti na področju matematike/znanosti, medtem ko so ženske poročale o večjem številu ustvarjalnih dosežkov na področju umetnosti. Do podobnih razlik pri samooceni ustvarjalnosti glede na spol je prišlo tudi v Kaufmanovi raziskavi iz leta 2006. Ženske so poročale o višji stopnji ustvarjalnosti na socialnem področju ter področju vizualne umetnosti, moški 
pa na znanstvenem in športnem področju. Kaufman je leta 2014 s sodelavci ugotovil konsistenten odnos med spolom in ustvarjalnimi dosežki na področju znanosti in umetnosti pri štirih različnih vzorcih (Kaufman idr., 2014).

Namen naše raziskave je bil sistematično raziskati merske značilnosti slovenskega prevoda Kaufmanovega vprašalnika ustvarjalnih področij s poudarkom na faktorski strukturi $\mathrm{z}$ uporabo konfirmatornega pristopa. S pomočjo velikih pet faktorjev osebnosti in ugotavljanjem razlik med spoloma pa smo do določene mere preverili tudi njegovo konstruktno veljavnost. Pričakovali smo pomembno pozitivno povezanost med lestvicami ustvarjalnosti, merjenimi $\mathrm{z}$ izbranim vprašalnikom, in petimi velikimi dimenzijami osebnosti, predvsem z odprtostjo in ekstravertnostjo (Kaufman, 2012, McKay idr., 2017). Na podlagi predhodnih raziskav smo predvidevali, da se bo nevroticizem najšibkejše in negativno povezoval z ustvarjalnostjo (Ma, 2009). Glede razlik med spoloma smo predvidevali, da bodo moški poročali o višji ustvarjalnosti na tehničnem/znanstvenem področju, ženske pa na umetniškem področju (Ivcevic in Mayer, 2009; Kaufman idr., 2014).

\section{Metoda}

\section{Udeleženci}

Slovenski prevod Kaufmanovega vprašalnika ustvarjalnih področij je rešilo 319 udeležencev. Zaradi velike količine manjkajočih podatkov smo izločili dva udeleženca. Končno število udeležencev je tako bilo 317, pri čemer je bilo 223 žensk (70 \%) in 94 moških (30 \%). Starost udeležencev se je gibala od 17 do 88 let s povprečno starostjo 37,92 let in standardno deviacijo 11,13 let. En odstotek udeležencev je imelo dokončano osnovno šolo, 34 \% udeležencev srednjo šolo in $65 \%$ udeležencev je imelo končano fakulteto. Dvanajst odstotkov udeležencev je imelo status študenta, $71 \%$ je bilo zaposlenih, $13 \%$ brezposelnih in $4 \%$ upokojenih.

\section{Pripomočki}

Kaufmanov vprašalnik ustvarjalnih področij. Vprašalnik K-DOCS (Kaufman Domains of Creativity Scale; Kaufman, 2012) meri samooceno posameznikove ustvarjalnosti na petih področjih, in sicer na osebnem/ medosebnem, študijskem, izvedbenem, tehničnem/ znanstvenem in umetniškem. Udeleženci so dobili navodilo, da na 5-stopenjski lestvici ( $1=$ veliko manj ustvarjalen, 5 = veliko bolj ustvarjalen) ocenijo, kako ustvarjalni so $\mathrm{v}$ primerjavi s posamezniki podobne starosti in s podobnimi življenjskimi izkušnjami. Pri postavkah, ki so opisovale vedenja oz. dejanja, s katerimi udeleženec ni imel predhodnih izkušenj, je navodilo od udeleženca zahtevalo oceno pogostosti izvedbe čim bolj podobnih vedenj oz. dejanj. Udeleženci so morali podati ocene na 50 postavkah, ki naj bi se združevale $\mathrm{v}$ pet lestvic, in sicer 11 postavk je sestavljalo osebno/ medosebno in študijsko lestvico, 10 postavk izvedbeno in 9 postavk tehnično/znanstveno in umetniško lestvico. Avtor vprašalnika je poročal o koeficientih zanesljivosti med 0,83 in 0,87 (Kaufman, 2012).
Vprašalnik je bil preveden v okviru vaj iz Psihologije osebnosti na Oddelku za psihologijo Filozofske fakultete Univerze v Ljubljani v študijskem letu 2015/16, kjer sta dve skupini študentov naredili neodvisni prevod, nato so prevoda združili in naredili konsenz, asistentka pa je naknadno preverila pravilnost prevodov. Nato je sledil vzvratni prevod $\mathrm{v}$ angleški jezik s strani prof. angleškega jezika. Na podlagi primerjanja vzvratnega prevoda $z$ originalom smo minimalno popravili pet postavk. Celoten postopek prevajanja je razviden iz tabel 5 in $6 \mathrm{v}$ prilogi.

Vprašalnik Velikih pet (BFI-K). Vprašalnik BFI-K (Big Five Questionnaire; Rammstedt in John, 2005; slovenska priredba: Zager Kocjan, 2016) meri pet velikih faktorjev osebnosti, ki predstavljajo temeljne osebnostne dimenzije v okviru petfaktorskega modela osebnosti in je skrajšana verzija dobro uveljavljenega vprašalnika Velikih pet BFI (Big Five Inventory; John, Donahue in Kentle, 1991; John in Srivastava, 1999). Obsega 21 postavk, med katerimi po štiri postavke merijo ekstravertnost, sprejemljivost, vestnost in nevroticizem, medtem ko lestvico odprtosti za izkušnje meri pet postavk. Pri vsaki postavki so morali udeleženci na 5stopenjski Likertovi ocenjevalni lestvici (od $1=$ sploh se ne strinjam do $5=$ popolnoma se strinjam) s številko označiti, v kolikšni meri se strinjajo z navedeno trditvijo. Skupni rezultat na posamezni lestvici predstavlja seštevek postavk, ki merijo posamezno osebnostno dimenzijo, pri čemer se osem postavk vrednoti obrnjeno. Raziskave kažejo, da ima BFI-K kljub manjšemu številu postavk zadovoljive merske značilnosti (koeficiente veljavnosti in faktorsko strukturo), kot prenizki so se izkazali koeficienti notranje konsistentnosti (Rammstedt in John, 2005, v slovenščini Zager Kocjan, 2016). Avtorica slovenske priredbe je poročala o koeficientih zanesljivosti od 0,58 pri dimenzijah ekstravertnost in sprejemljivost do 0,69 pri dimenziji nevrotizicem (Zager Kocjan, 2016). V naši raziskavi so bili koeficienti zanesljivosti nekoliko višji in so se gibali med 0,62 za dimenzijo sprejemljivost in $0,78 \mathrm{za}$ dimenzijo nevroticizem.

\section{Postopek}

Podatke smo zbirali od julija 2015 do septembra 2016 prek spleta po metodi snežne kepe. V naboru vprašalnikov, ki so jih udeleženci izpolnjevali, so poleg vprašalnikov K-DOCS in BFI-K udeleženci izpolnili še vprašalnike o humorju in subjektivnem blagostanju. Vprašalniki so bili postavljeni na spletni platformi $1 \mathrm{ka}$. V nagovoru smo prosili za sodelovanje pri raziskavi in ponudili individualne povratne informacije. Iz demografskega vidika (spol, starost) $\mathrm{v}$ nagovoru nismo omejevali ciljne skupine udeležencev. Povezavo do vprašalnikov smo poslali preko elektronske pošte treh psihologov, objavili na Facebook spletni strani ter na spletni strani psiha.net. Pomoč pri zbiranju podatkov nam je nudilo tudi Društvo študentov psihologije Slovenije (DŠPS), ki je poslalo nagovor s povezavo na anketo svojim članom. Udeleženci so podali informirano soglasje, v katerem smo jim zagotovili, da bodo javno objavljeni in dostopni le skupinski rezultati, pri čemer njihova identiteta $\mathrm{v}$ nobenem primeru ne bo razkrita. 


\section{Analiza podatkov}

Podatke smo najprej obdelali s statističnim programom SPSS 20.0 (IBM Corp., 2011) (pregled frekvenc, normalnosti, manjkajoči podatki). V programu Mplus 7 (Muthén in Muthén, 1998-2015) smo nato s konfirmatorno faktorsko analizo preverili ustreznost faktorske strukture, za tem pa ponovno v programu SPSS 20.0 (IBM. Corp., 2011) izračunali opisne statistike za parcele, ki sestavljajo Kaufmanov vprašalnik ustvarjalnih področij, Pearsonove koeficiente korelacije med področji Kaufmanovega vprašalnika ustvarjalnih področij in osebnostnimi lastnostmi merjenimi z BFI-K ter naredili $t$-test za neodvisne vzorce. Korelacije med faktorji K-DOCS smo povzeli tako kot izhajajo iz konfirmatorne faktorske analize, ki smo jo naredili v programu Mplus7 (Muthén in Muthén, 1998-2015).

\section{Rezultati z razpravo}

Prileganje petfaktorskega modela (Kaufman, 2012) smo preverili $\mathrm{v}$ dveh korakih $\mathrm{z}$ uporabo konfirmatorne faktorske analize (KFA) v programu Mplus7 (Muthén in Muthén, 1998 - 2015). Uporabili smo podobno metodologijo kot so jo uporabili McKay in sodelavci (2017) pri validaciji vprašalnika v angleškem in poljskem jeziku. Konfirmatorno faktorsko analizo smo v prvem koraku izvedli tako, da smo uporabili vseh 50 postavk kot manifestne spremenljivke, pri čemer smo, v nasprotju $\mathrm{z}$ avtorji validacijske študije, ki so uporabili cenilko največjega verjetja (ML), uporabili cenilko WLSMV (robustna cenilka obteženih najmanjših kvadratov), ki je privzeta cenilka za ordinalne spremenljivke. Čeprav lahko 5-stopenjske lestvice pogojno obravnavamo kot zvezne (Rhemtulla, Brosseau-Liard in Savalei, 2012), smo se za cenilko WLSMV odločili tudi zaradi zmernega odstopanja porazdelitve postavk od normalne porazdelitve; mere asimetričnosti od $-0,50$ do $0,46(S E=0,14)$ ter mere sploščenosti od $-0,71$ do $0,91(S E=0,27)$.

$\mathrm{V}$ drugem koraku smo v skladu z raziskavo avtorja McKay in sodelavcev (2017) KFA izvedli tako, da smo postavke združili v parcele. Za oblikovanje parcel smo se odločili zaradi relativno majhnega razmerja med številom postavk (50) in številom udeležencev (317), ki lahko pomembno prispeva $\mathrm{h}$ kvaliteti rezultatov, predvsem ko vzorec udeležencev ni zelo velik (Osborne in Costello, 2004). Parcele smo oblikovali tako, da smo združili postavke, ki so bile pri konfirmatorni faktorski analizi najbolj in najmanj nasičene s posameznim faktorjem, saj smo tako uravnovesili parcele in se izognili velikim razlikam med njihovimi nasičenostmi s faktorjem (Little, Cunningham in Shahar, 2002; Little, Rhemtulla, Gibson in Schoemann, 2013). Glede na to, da naj bi se s posameznim faktorjem povezovalo različno število postavk, smo kot vrednost parcel vzeli povprečje treh ali štirih postavk, tako da smo dobili za vsak faktor tri parcele, ki so predstavljale manifestne spremenljivke za posamezen faktor. Tovrstna metodologija je enaka metodologiji, ki so jo uporabili McKay in sodelavci leta 2017 in nam zato omogoča neposredno primerjavo z pridobljenimi rezultati, ki je razvidna iz tabele 1 . Tudi $v$ tem primeru smo zaradi zmernega odstopanja porazdelitve postavk od normalne porazdelitve uporabili robustno cenilko največjega verjetja (MLR) in ne cenilko največjega verjetja (ML). Sestavljenost parcel in njihove opisne statistike so razvidne iz tabele 2.

Kot je razvidno iz tabele 1 naši rezultati prikazujejo primerljivo prileganje 5-faktorskemu modelu kot rezultati, ki so jih dobili McKay in sodelavci (2017). Avtorji so v svoji raziskavi uporabili kriterije, $\mathrm{v}$ skladu s katerimi bi morale biti vrednosti CFI in TLI višje od 0,95, vrednosti RMSEA in SRMR pa manjše od 0,10 (McKay idr., 2017). Ko smo uporabili vseh 50 postavk kot manifestne spremenljivke, so bile vrednosti indeksov CFI in TLI nižje od postavljenih kriterijev, vendar višje od njihovih, medtem ko je bila vrednost indeksa RMSEA znotraj kriterijev, čeprav višja od vrednosti, ki so jih dobili McKay in sodelavci. Povprečne nasičenosti postavk po posameznih faktorjih so bile $0,61 \mathrm{~s}$ faktorjem osebne/medosebne ustvarjalnosti, $0,73 \mathrm{~s}$ faktorjem študijske ustvarjalnosti, $0,76 \mathrm{~s}$ faktorjem tehnične/znanstvene in umetniške ustvarjalnosti ter $0,77 \mathrm{~s}$ faktorjem izvedbene ustvarjalnosti. Nobena postavka ni imela nasičenosti s faktorjem manjše od 0,40, kar je bil Kaufmanov kriterij za izločitev postavk pri oblikovanju vprašalnika (Kaufman, 2012). Pri analizi, kjer smo uporabili parcele kot manifestne spremenljivke, pa so vrednosti vseh indeksov izpolnjevale kriterije, pri čemer so kazale na boljše ali enako prileganje modela kot vrednosti, ki so jih dobili McKay in sodelavci pri validaciji vprašalnika $\mathrm{v}$ poljskem in $\mathrm{v}$ angleškem jeziku. V skladu z zaključki njihove raziskave lahko sklenemo, da rezultati KFA tudi $\mathrm{v}$ našem primeru nudijo podporo 5faktorski strukturi, ki jo je dobil Kaufman v njegovi originalni raziskavi iz leta 2012. Povprečne standardizirane nasičenosti parcel po posameznih faktorjih so bile $0,79 \mathrm{~s}$ faktorjem osebne/medosebne ustvarjalnosti, 0,89 s faktorjem študijske, izvedbene in umetniške ustvarjalnosti ter $0,87 \mathrm{~s}$ faktorjem tehnične/znanstvene ustvarjalnosti.

Tabela 1. Primerjava naših rezultatov preverjanja prileganja 5-faktorskega modela vprašalnika K-DOCS z rezultati McKay in sodelavcev (2017)

\begin{tabular}{lrrrrrrr}
\hline & $\chi^{2}$ & $d f$ & CFI & TLI & RMSEA [90 \% IZ] & SRMR & WRMR \\
\hline Vse spremenljivke - slovenski & $\mathbf{3 4 2 3 , 0 9}$ & $\mathbf{1 1 6 5}$ & $\mathbf{, 8 4 8}$ & $\mathbf{, 8 4 1}$ & $\mathbf{, 0 7 8}[, 075-\mathbf{, 0 8 1}]$ & $/$ & $\mathbf{1 , 9 9 2}$ \\
Vse spremenljivke - angleški* & 5214,57 & 1165 &, 801 &, 791 &, $065[, 063-, 067]$ &, 061 & $/$ \\
Vse spremenljivke - poljski* & 3822,58 & 1165 &, 769 &, 757 &, $068[, 065-, 070]$ &, 072 & $/$ \\
Parcele - slovenski & $\mathbf{1 6 3 , 2 3}$ & $\mathbf{8 0}$ & $\mathbf{, 9 7 2}$ & $\mathbf{, 9 6 4}$ & $\mathbf{, 0 5 7}[, \mathbf{0 4 5}-\mathbf{, 0 7 0 ]}$ & $\mathbf{, 0 4 5}$ & $/$ \\
Parcele - angleški* & 320,55 & 80 &, 973 &, 964 &, $060[, 054-, 097]$ &, 034 & $/$ \\
Parcele - poljski* & 354,05 & 80 &, 944 &, 927 &, $083[, 074-, 092]$ &, 050 & $/$ \\
\hline
\end{tabular}

Opombe. Rezultati označeni z * so povzeti po McKay idr., 2017, str. 220. 
Tabela 2. Opisne statistike, zanesljivosti in standardizirane uteži postavk ter parcel

\begin{tabular}{|c|c|c|c|c|c|c|c|c|c|}
\hline faktor K-DOCS & parcela & $\begin{array}{l}\text { postavke v } \\
\text { parceli }\end{array}$ & $\begin{array}{l}\text { standardizirane } \\
\text { uteži (postavke) }\end{array}$ & $\begin{array}{l}\text { standardizirane } \\
\text { uteži (parcele) }\end{array}$ & $M$ & $S D$ & As & $S p l$ & $\alpha$ \\
\hline \multirow{3}{*}{$\begin{array}{l}\text { Osebna/ } \\
\text { medosebna }\end{array}$} & Parcela 1 & $5,6,7,9$ &, $45-, 70$ &, 84 & 3,74 &, 59 &,- 34 & ,53 & \multirow{3}{*}{, 82} \\
\hline & Parcela 2 & $3,4,8,11$ & ,46-,69 &, 85 & 3,70 & ,56 &,- 50 & ,91 & \\
\hline & Parcela 3 & $1,2,10$ & ,53-,69 & ,67 & 3,73 & ,60 &,- 38 &, 18 & \\
\hline \multirow{3}{*}{ Študijska } & Parcela 1 & $13,16,17,18$ &, $48-, 82$ & ,90 & 3,28 & ,73 &,- 23 & 00 & \multirow{3}{*}{,92 } \\
\hline & Parcela 2 & $12,19,21,22$ &, $63-, 81$ & ,89 & 3,38 & ,68 &,- 30 & ,42 & \\
\hline & Parcela 3 & $14,15,20$ & ,71-,78 &, 87 & 3,30 &, 73 &,- 23 & ,09 & \\
\hline \multirow{3}{*}{ Izvedbena } & Parcela 1 & $23,26,29,32$ &, $63-, 89$ & ,90 & 2,29 &, 89 & ,46 &,- 16 & \multirow{3}{*}{,92 } \\
\hline & Parcela 2 & $24,27,28$ & ,64-,89 & ,90 & 2,54 & ,93 &, 25 &,- 45 & \\
\hline & Parcela 3 & $25,30,31$ &, $70-, 83$ & ,88 & 2,46 & ,99 & ,42 &,- 38 & \\
\hline \multirow{3}{*}{$\begin{array}{l}\text { Tehnična/ } \\
\text { znanstvena }\end{array}$} & Parcela 1 & $33,34,38$ &, $61-, 89$ & ,84 & 2,76 & ,98 & ,09 &,- 58 & \multirow{3}{*}{,90 } \\
\hline & Parcela 2 & $35,40,41$ &, $66-, 87$ & ,88 & 2,39 & ,95 & ,31 &,- 58 & \\
\hline & Parcela 3 & $36,37,39$ &, $70-, 81$ &, 89 & 2,90 & ,99 &,- 05 &,- 71 & \\
\hline \multirow{3}{*}{ Umetniška } & Parcela 1 & $42,45,50$ & ,63-,93 & ,95 & 3,22 & ,92 &,- 18 &,- 34 & \multirow{3}{*}{,92 } \\
\hline & Parcela 2 & $43,44,46$ & ,63-,89 & ,88 & 3,36 &, 88 &,- 19 &,- 39 & \\
\hline & Parcela 3 & $47,48,49$ &, $66-, 81$ & ,84 & 3,21 & ,90 &,- 14 &,- 43 & \\
\hline
\end{tabular}

Opombe. $N=317 . S E$ za asimetričnost $=, 14 ; S E$ za sploščenost $=, 27$

Iztabele 2 lahko razberemo aritmetične sredine, standardne deviacije, koeficiente asimetričnosti in sploščenosti ter alfa koeficiente notranje konsistentnosti parcel. Koeficienti asimetričnosti kažejo na to, da so porazdelitve odgovorov na posameznih parcelah nekoliko asimetrične, in sicer ene $\mathrm{v}$ levo druge pa $\mathrm{v}$ desno. Koeficienti sploščenosti ravno tako kažejo na razlike med porazdelitvami posameznih lestvic, saj so nekatere nekoliko sploščene, druge pa koničaste, vendar pa odstopanja od normalne porazdelitve niso velika. Udeleženci so najvišje povprečne rezultate dosegli na osebni/medosebni ustvarjalnosti, najnižji pa pri izvedbeni ustvarjalnosti. Ravno tako so ustrezne zanesljivosti lestvic, saj so njihove vrednosti na vseh lestvicah 0,82 ali več.

Nadalje smo preverili konstruktno veljavnost prek pregleda korelacij med velikimi petimi faktorji osebnosti in petimi področji ustvarjalnosti. Iz tabele 3 je razvidno, da so se naši rezultati $\mathrm{v}$ veliki meri ujemali $\mathrm{z}$ rezultati, o katerih poroča
Kaufman (2012) v originalni raziskavi. Odprtost za izkušnje se je pričakovano najvišje povezovala $\mathrm{z}$ ustvarjalnostjo. Tako kot $\mathrm{v}$ originalni raziskavi se je statistično pomembno pozitivno povezovala $\mathrm{z}$ vsemi področji razen s tehničnim/ znanstvenim. Povezava med ustvarjalnostjo in odprtostjo je smiselna, saj so posamezniki z visoko izraženo odprtostjo za izkušnje radovedni, nekonvencionalni ter zainteresirani $\mathrm{za}$ intelektualne teme ter teme povezane $\mathrm{z}$ umetnostjo in kulturo. Take osebe so uspešnejše na skoraj vseh nalogah, ki zahtevajo ustvarjalnost, izbirajo ustvarjalne hobije, izbirajo študije, ki jim omogočajo izražanje ustvarjalnosti in imajo več ustvarjalnih dosežkov v svojem življenju (Conner in Silvia, 2015). Glede na to, da je ekstravertnost pomemben napovednik samoocene učinkovitosti reševanja problemov, oblikovanja idej in ustvarjalnosti (Karwowski in Lebuda, 2015), ni presenetljivo, da smo enak vzorec korelacij ugotovili pri ekstravertnosti, ki se je ravno tako statistično pomembno

Tabela 3. Pearsonovi koeficienti korelacij med področji Kaufmanovega vprašalnika ustvarjalnih področij in osebnostnimi lastnostmi merjenimi z BFI-K

\begin{tabular}{|c|c|c|c|c|c|c|c|c|c|}
\hline & 2. & 3. & 4. & 5. & 6. & 7. & 8. & 9. & 10. \\
\hline 1. Osebna/medosebna &, $53^{* *}$ & $25^{* *}$ &, $12^{*}$ &, $34^{* *}$ & $37^{* *}$ & $29^{* *}$ & $29^{* *}$ &,$- 33^{* *}$ & $37^{* *}$ \\
\hline 2. Študijska & & $34^{* *}$ & $24^{* *}$ &, $32^{* *}$ & $19^{* *}$ & 02 &, $17^{* *}$ &,- 10 &, $39^{* *}$ \\
\hline 3. Izvedbena & & &, $26^{* *}$ &, $40^{* *}$ &, $12^{*}$ &, 02 & 01 & 03 &, $36^{* *}$ \\
\hline 4. Tehnična/znanstvena & & & &, $49^{* *}$ &,- 09 &, 04 &,- 01 &,- 11 &, 04 \\
\hline 5. Umetniška & & & & &, $13^{*}$ & ,08 & 03 &,- 08 &, $50^{* *}$ \\
\hline 6. Ekstravertnost & & & & & &, $13^{*}$ &, $14^{*}$ &,$- 23^{* *}$ &, $31^{* *}$ \\
\hline 7. Sprejemljivost & & & & & & &, $16^{* *}$ &,$- 52^{* *}$ &, 08 \\
\hline 8. Vestnost & & & & & & & &,$- 20^{* *}$ &, $18^{* *}$ \\
\hline 9. Nevroticizem & & & & & & & & &,$- 13^{*}$ \\
\hline 10. Odprtost & & & & & & & & & \\
\hline
\end{tabular}

Opombe. $N=316$ (ena oseba ni rešila vprašalnika BFI-K), ${ }^{*} p<, 05 ;{ }^{* *} p<, 01$. 
Tabela 4. Razlike med spoloma na posameznih področjih ustvarjalnosti

\begin{tabular}{|c|c|c|c|c|c|c|c|c|}
\hline \multirow[b]{2}{*}{ Lestvice K-DOCS } & \multicolumn{2}{|c|}{ moški } & \multicolumn{2}{|c|}{ ženske } & \multirow[b]{2}{*}{$t$} & \multirow[b]{2}{*}{$d f$} & \multirow[b]{2}{*}{$p$} & \multirow[b]{2}{*}{ Cohenovd } \\
\hline & $M$ & $S D$ & $M$ & $S D$ & & & & \\
\hline 1. Osebna/medosebna & 40,67 & 5,55 & 41,07 & 5,51 & $-0,59$ & 173,81 & 556 & ,07 \\
\hline 2. Študijska & 33,90 & 7,41 & 32,50 & 6,61 & 1,59 & 158,50 &, 114 &, 21 \\
\hline 3. Izvedbena & 24,69 & 9,07 & 23,93 & 8,49 & 0,69 & 165,05 & ,489 & ,09 \\
\hline 4. Tehnična/znanstvena & 21,28 & 6,53 & 17,39 & 6,24 & 4,91 & 167,83 &, 000 & ,62 \\
\hline 5. Umetniška & 33,00 & 8,82 & 35,90 & 9,07 & $-2,65$ & 179,42 & 009 &, 32 \\
\hline
\end{tabular}

Opombe. $N($ moški $)=94, N(\check{z}$ enske $)=223$.

pozitivno povezovala $\mathrm{z}$ vsemi področji ustvarjalnosti razen $\mathrm{S}$ tehničnim/znanstvenim. Podobno kot $\mathrm{v}$ Kaufmanovi raziskavi (2012) se je vestnost statistično pomembno pozitivno povezovala s študijsko ustvarjalnostjo, v nasprotju s predhodnimi ugotovitvami pa je statistično pomembno pozitivno korelirala tudi z osebno/medosebno ustvarjalnostjo, $\mathrm{s}$ katero se je pomembno pozitivno povezovala tudi sprejemljivost. Povezava med vestnostjo in ustvarjalnostjo na študijskem področju je smiselna, saj je za tovrstno ustvarjalnost potrebna vztrajnost, natančnost in organiziranost. Ravno tako ni presenetljiva povezanost med sprejemljivostjo in osebno/medosebno ustvarjalnostjo, saj slednja vključuje tudi ustvarjalnost pri reševanju problemov v medosebnih odnosih. Nekoliko težje pa je pojasniti povezanost med vestnostjo in osebno/medosebno ustvarjalnostjo. Povezanost bi lahko bila posledica vztrajnosti, ki je potrebna pri reševanju osebnih in medosebnih problemov, ki so zajeti v osebno/medosebni ustvarjalnosti. Nevroticizem se je statistično pomembno negativno povezoval z osebno/medosebno ustvarjalnostjo, kar bi lahko bilo posledica dejstva, da lahko posameznik doživi več neuspehov, preden uspešno naredi nekaj ustvarjalnega na tem področju. To lahko pri čustveno manj stabilnemu posamezniku povzroči, da zadevo opusti, torej o višji ustvarjalnosti na osebnem/medosebnem področju poročajo bolj čustveno stabilni posamezniki. Če povzamemo rezultate povezanosti samoocen ustvarjalnosti s petimi velikimi, lahko rečemo, da so pridobljene povezave večinoma pričakovane in smiselne ter tako kažejo na ustrezno konstruktno veljavnost prevoda Kaufmanovega vprašalnika ustvarjalnih področij.

Ker več avtorjev ugotavlja, da se moški in ženske med seboj razlikujejo $\mathrm{v}$ tem, na katerem področju poročajo o najvišji ustvarjalnosti (Ivcevic in Mayer, 2009; Kaufman idr.,2010; Kaufman, 2006, Kaufman idr., 2014), smo tudi na našem vzorcu preverili razlike med spoloma. Naši rezultati so skladni $\mathrm{z}$ ugotovitvami predhodnih raziskav, kar je razvidno iz tabele 4. Podobno kot v predhodnih Kaufmanovih raziskavah (Kaufman, 2006; Kaufman idr., 2010) so moški poročali o statistično pomembno višji stopnji ustvarjalnosti na področju tehniške/znanstvene ustvarjalnosti, medtem ko so ženske poročale o statistično pomembno višji ustvarjalnosti na področju umetnosti. Cohenov $d$ je pokazal majhen do srednje velik učinek na umetniškem področju ter srednji do velik učinek na področju tehnične/znanstvene ustvarjalnosti. Pridobljeni rezultati so lahko posledica družbenih vlog, ki od žensk še vedno zahtevajo, da več pozornosti posvetijo branju, pisanju in ustvarjanju, od moških pa, da so bolj dejavni na poklicnem področju (Abraham, 2016). Poleg pričakovanih razlik se je $\mathrm{v}$ našem vzorcu pokazala tudi majhna velikost učinka na študijskem področju, čeprav testiranje statistične pomembnosti ni pokazalo statistično pomembnih razlik. Moški so se na tem področju ocenili nekoliko višje kot ženske, kar bi lahko bilo posledica tega, da se v akademskem svetu daje večji poudarek na tehnične/znanstvene dosežke, na katerih so se moški ravno tako ocenili kot statistično pomembno bolj ustvarjalni.

Ugotovljene razlike med spoloma se torej ujemajo $\mathrm{z}$ ugotovitvami prehodnih raziskav (Kaufman, 2006, Kaufman idr., 2010), kar poleg skladnega vzorca povezanosti med različnimi vidiki ustvarjalnosti in osebnostjo kaže na zadovoljivo konstruktno veljavnost prevoda Kaufmanovega vprašalnika ustvarjalnih področij.

\section{Zaključki}

Namen raziskave je bil preveriti merske značilnosti slovenske oblike Kaufmanovega vprašalnika ustvarjalnih področij. Naši rezultati kažejo, da ima slovenska oblika obravnavanega vprašalnika sprejemljive merske značilnosti in je posledično primerna za samooceno ustvarjalnosti na petih izbranih področjih.

Najprej smo preverili veljavnost notranje strukture slovenskega prevoda Kaufmanovega vprašalnika ustvarjalnih področij. Naši rezultati kažejo nekoliko boljše prileganje 5-faktorskega modela kot rezultati, ki so jih dobili McKay in sodelavci (2017). Enako kot oni smo tudi mi preverili prileganje modela na dva načina, in sicer najprej z uporabo posameznih postavk kot manifestnih spremenljivk, $v$ drugem koraku pa $\mathrm{z}$ uporabo parcel. V obeh primerih vrednosti indeksov kažejo na dobro prileganje 5-faktorskega modela, pri čemer je bilo pričakovano boljše pri uporabi parcel. Povprečne nasičenosti posameznih postavk po posameznih faktorjih so bile zadovoljivo visoke, saj ni imela nobena postavka nasičenosti s faktorjem manjše od 0,40. Ravno tako so bile zadovoljivo visoke povprečne nasičenosti parcel po posameznih faktorjih.

Povezanost petih področij ustvarjalnosti $\mathrm{z}$ velikimi petimi faktorji osebnosti je bila skladna s pričakovanji in predhodnimi ugotovitvami (McKay idr., 2017). Odprtost za izkušnje se je najvišje povezovala s področji ustvarjalnosti, kar je pričakovano, saj so posamezniki z visoko izraženo odprtostjo za izkušnje radovedni in zainteresirani za teme, povezane z umetnostjo in kulturo (Conner in Silvia, 2015). Podoben vzorec korelacij smo ugotovili pri ekstravertnosti, kar ravno tako ni presenetljivo, saj je ekstravertnost napovednik samoocene učinkovitosti reševanja problemov, oblikovanja idej in ustvarjalnosti (Karwowski in Lebuda, 2015). 
Podobno kot v Kaufmanovi raziskavi (2012) se je vestnost pričakovano statistično pomembno pozitivno povezovala s študijsko ustvarjalnostjo, saj je za tovrstno ustvarjalnost potrebna vztrajnost, natančnost in organiziranost. Ravno tako ni presenetljiva povezanost med sprejemljivostjo in osebno/medosebno ustvarjalnostjo, saj slednja vključuje tudi ustvarjalnost pri reševanju problemov $\mathrm{v}$ medosebnih odnosih. Nevroticizem se je statistično pomembno negativno povezoval $\mathrm{z}$ osebno/medosebno ustvarjalnostjo, kar je lahko posledica dejstva, da je za vztrajanje pri ustvarjalnih vedenjih na osebnem/medosebnem področju, kljub številnim neuspehom, potrebna določena mera čustvene stabilnosti.

Ravno tako so se pokazale pričakovane razlike med spoloma, saj so moški poročali o statistično pomembno višji stopnji ustvarjalnosti na področju tehniške/znanstvene ustvarjalnosti, medtem ko so ženske poročale o statistično pomembno višji ustvarjalnosti na področju umetnosti. Ugotovljene razlike med spoloma se torej ujemajo $\mathrm{Z}$ ugotovitvami prehodnih raziskav (Kaufman, 2006, Kaufman idr., 2010) in tako potrjujejo zadovoljivo konstruktno veljavnost prevoda Kaufmanovega vprašalnika ustvarjalnih področij.

Pomanjkljivost naše raziskave predstavlja nereprezentativnost vzorca, saj je priložnosten, delež moških je manjši od ene tretjine, tudi starostno je zelo heterogen. Ker vprašalnik vključuje specifična vedenja, med katerimi so tudi taka, ki so tradicionalno povezana $\mathrm{z}$ posameznim spolom, bi bilo smiselno preveriti mersko invariantnost prek spola, vendar naš vzorec tega ni omogočal. Zaradi kratkosti vprašalnika BFI so alfa koeficienti posameznih lestvic precej nizki, kar je lahko razlog za nižje korelacije med obema uporabljenima vprašalnikoma, zato bi bilo v prihodnjih raziskavah smiselno uporabiti daljšo verzijo vprašalnika osebnosti.

V prihodnosti bi bilo smiselno preveriti pogostost vedenj, vključenih $\mathrm{v}$ pričujoči vprašalnik, ki sicer meri stopnjo ustvarjalnosti in ne pogostosti. Postavlja se vprašanje, kakšna je samoocena ustvarjalnosti vedenja, ki ga posameznik še ni izvajal? Vprašalnik namreč zahteva, da oseba, ki navedenega vedenja še ni izvedla, oceni svojo ustvarjalnost pri podobnem vedenju, pri čemer so lahko nekatera vedenja tako redka, da je posameznikova ocena ustvarjalnosti tega vedenja lahko zelo netočna. Morda je ravno redkost vedenja vzrok, da sta se postavki, ki se nanašata na izrezovanje iz lesa ali konstruiranje iz kovine ali kamna, izkazali za problematični (sta bili podobno nasičeni $\mathrm{z}$ dvema faktorjema). Po drugi strani pa pogostost nekega vedenja ne more biti pokazatelj stopnje ustvarjalnosti, saj posameznik npr. lahko pogosto piše kratka elektronska sporočila $\mathrm{v}$ verzih, a v njih ni prav nič ustvarjalnega.

Pomanjkljivost predstavlja tudi dejstvo, da je vprašalnik strukturiran tako, da ima postavke, ki sestavljajo isti faktor, razporejene po blokih. Taka razporeditev lahko vpliva na zanesljivost rezultatov in nasičenosti s faktorjem, saj lahko udeleženci opazijo, da so si postavke med seboj sorodne oziroma se navezujejo na isto področje in posledično podajo na te postavke bolj podobne odgovore, ki zaradi tega močneje korelirajo med seboj kot z ostalimi postavkami.

Ne glede na omenjene pomanjkljivosti pa opisana raziskava predstavlja potrditev, da je slovenska oblika Kaufmanovega vprašalnika ustvarjalnih področij zanesljiv in konstruktno veljaven inštrument, ki ga bodo lahko raziskovalci uporabljali pri raziskovanju odnosov med dejanskimi ustvarjalnimi dosežki, ustvarjalnim potencialom in drugimi konkretnimi merami ustvarjalnosti ter njenimi napovedniki in izidi. Lestvica bo uporabna tudi za raziskovanje odnosov med tako merjeno ustvarjalnostjo in drugimi psihološkimi konstrukti, $\mathrm{s}$ čimer bodo lahko obogatili razumevanje ustvarjalnosti v slovenskem okolju.

\section{Literatura}

Abraham, A. (2016). Gender and creativity: An overview of psychological and neuroscientific literature. Brain Imaging and Behavior, 10(2), 609-618.

Abraham, A. in Windmann, S. (2007). Creative cognition: The diverse operations and the prospect of applying a cognitive neuroscience perspective. Methods, 42, 38-48.

Allen, A. P. in Thomas, K. E. (2011). A dual process account of creative thinking. Creativity Research Journal, 23(2), $109-118$.

Carmeli, A. McKay, A. S. in Kaufman, J. C. (2013). Emotional intelligence and creativity: The mediating role of generosity and vigor. The Journal of Creative Behavior, 48(4), 290-309.

Carson, S., Peterson, J. B. in Higgins, D. M. (2005). Reliability, validity and factor structure of the Creative achievement questionnaire. Creativity Research Journal, 17(1), 37-50.

Conner, T. S. in Silvia, P. J. (2015). Creative days: A daily diary study of emotion, personality and everyday creativity. Psychology of Aesthetics, Creativity and the Arts, 9(4), 463-470.

Csikszentmihalyi, M. (1997). Creativity: An overview. V M. Csikszentmihalyi (ur.), Creativity: Flow and the psychology of discovery and invention (str. 337-342). New York, NY, ZDA: Harper Collins Publishers.

DeYoung, C. G., Quilty, L. C., Peterson, J. B. in Gray, J. R. (2014). Openness to experience, intellect and cognitive ability. Journal of Personality Assessment, 96(1), 46-52.

Dollinger, S. J., Urban, K. K. in James, T. A. (2004). Creativity and openness: Further validation of two creative product measures. Creativity Research Journal, 16(1), 35-47.

Feist, G. J. (2010). The function of personality in creativity: The nature and nurture of the creative personality. V J. C. Kaufman in R. J. Sternberg (ur.), The Cambridge handbook of creativity (str. 113-130). New York: Cambridge university press.

Feist, G. J. in Barron, F. X. (2003). Predicting creativity from early to late adulthood: Intellect, potential and personality. Journal of Research in Personality, 37(2), 62-88.

Fürst, G., Ghisletta, P. in Lubart T. (2012). The creative process in visual art: A longitudinal multivariate study. Creativity Research Journal, 24(4), 283-295.

Glăveanu, V. P. (2019). Measuring creativity across cultures: Epistemological and methodological considerations. Psychology of Aesthetics, Creativity and the Arts, 13(2), 227-232.

Grosul, M. in Feist G. J. (2014). The creative person in science. Psychology of Aesthetics, Creativity and the Arts, 8(1), 30-43. 
Guilford, J. P. (1950). Creativity. American Psychologist, 5, 444-454.

IBM Corp. (2011). IBM SPSS Statistics for Windows, Version 20.0. Armonk, NY, ZDA: IBM Corp.

Ivcevic, Z., Brackett, M. A. in Mayer, J. D. (2007). Emotional intelligence and emotional creativity. Journal of Personality, 75(2), 199-235.

Ivcevic, Z. in Mayer, J. D. (2009). Mapping dimensions of creativity in the life-space. Creativity Research Journal, 2(2-3), 152-165.

Jeon, K., Moon, S. M. in French, B. (2011). Differential effects of divergent thinking, domain knowledge, and interest on creative performance in art and math. Creativity Research Journal, 23(1), 60-71.

John, O. P., Donahue, E. M. in Kantle, R. L. (1991). The Big Five Inventory-versions $4 a$ and 54. Berkeley, CA, ZDA: University of California, Berkeley, Institute of personality and social research.

John, O. P. in Srivastava, S. (1999). The Big five trait taxonomy: History, measurement and theoretical perspectives. V L. A. Pervin in O. P. John (ur.), Handbook of personality: Theory and research (str. 102-139). New York, NY, ZDA: Guilford press.

Karwowski, M. in Lebuda, I. (2015). The big five, the huge two and creative self-beliefs: A meta-analysis. Psychology of Aesthetics, Creativity and the Arts, 10(2), 214-232.

Kaufman, J. C. (2006). Self-reported differences in creativity by ethnicity and gender. Applied Cognitive Psychology, 20, 1065-1082.

Kaufman, J. C. (2012). Counting the muses: Development of the Koufman Domains of Creativity Scale (K-DOCS). Psychology of Aesthetics, Creativity and the Arts, 6(4), 298-308.

Kaufman, J. C. in Bear, J. (2004). Sure, I'm creative - but not in mathematics!: Self-reported creativity in diverse domains. Empirical Studies of the Arts, 22(2), 143-155.

Kaufman, J. C. in Baer, J. (2012). Beyond new and appropriate: Who decides what is creative? Creativity Research Journal, 24(1), 83-91.

Kaufman, J. C., Quilty, L. C., Grazioplene, R. G., Hirsh, J. B., Gray, J. R., Peterson, J. B. in DeYoung, C. G. (2014). Openness to experience and intellect differentially predict creative achievement in the arts and sciences. Journal of Personality, 84(2), 248-258.

Kaufman, J. C., Waterstreet, M. A., Ailabouni, H. S., Whitcomb, H. J., Roe, A. K. in Riggs, M. (2010). Personality and self-perceptions of creativity across domains. Imagination, Cognition and Personality, 29(3), 193-209.

Kim, K. H. (2005). Can only intelligent people be creative? A meta-analysis. The Journal of Secondary Gifted Education, 16(2/3), 57-66.

Little, T. D., Cunningham, W. A. in Shahar, G. (2002). To parcel or not to parcel: Exploring the questions, weighing the merits. Structural Equation Modeling, 9(2), 151-173.

Little, T. D., Rhemtulla, M., Gibson, K. in Schoemann, M. (2013). Why the item versus parcels controversy needn't be one. Psychological Methods, 18(3), 285-300.

Ma, H. (2009). The effect size of variables associated with creativity: A meta-analysis. Creativity Research Journal, 21(1), 30-42.
McKay, A. S., Karwowski, M. in Kaufman, J. C. (2017). Measuring the muses: Validating the Kaufman Domains of Creativity Scale (K-DOCS). Psychology of Aesthetics, Creativity, and the Arts, 11(2), 216-230.

Miller, A. L. (2014). A self-report measure of cognitive processes associated with creativity. Creativity Research Journal, 26(2), 203-218.

Muthén, L. K. in Muthén, B. O. (1998 - 2015). Mplus user'sguide ( $7^{\text {th }}$ ed.). Los Angeles, CA, ZDA: Muthén \& Muthén.

Osborne, J. W. in Costello, A. B. (2004). Sample size and subject to item ratio in principal component analysis. Practical Assessment, Research \& Evolution, 9(11), 9-19.

Piffer, D. (2012). Can creativity be measured? An attempt to clarify the notion of creativity and general direction for future research. Thinking Skills and Creativity, 7, 258-264.

Pretz, J. E. in McCollum, V. A. (2014). Self-perceptions of creativity do not always reflect actual creative performance. Psychology of Aesthetics, Creativity and the Arts, 8(2), 227-236.

Rammstedt, B. in John, O. P. (2005). Kurzversion des Big five inventory (BFI-K): Entwicklung und Validierung eines ökonomischen Inventars zur Erfassung der fünf Faktoren der Persönlichkeit [Kratka oblika Vprašalnika Velikih Pet (BFI-K): Razvoj in validacija kratkega vprašalnika za ocenjevanje petih faktorjev osebnosti]. Diagnostica, 51(4), 195-206.

Rhemtulla, M., Brosseau-Liard, P. E. in Savalei, V. (2012). When can categorical variables be treated as continuous? A comparison of robust continuous and categorical SEM estimation methods under suboptimal conditions. Psychological Methods, 17, 354-373.

Runco, M. A. in Jaeger, G. J. (2012). The standard definition of creativity. Creativity Research Journal, 24, 92-96.

Silvia, P. (2018). Creativity is undefinable, controllable, and everywhere. V R. Sternberg in J. Kaufman (ur.), The nature of human creativity (str. 291-301). Cambridge, Združeno kraljestvo: Cambridge University Press.

Silvia, P. J., Wigert, B., Reiter-Palmon, R. in Kaufman, J. C. (2012). Assessing creativity with self-report scales: A review and empirical evaluation. Psychology of Aesthetics, Creativity and the Arts, 6(1), 19-34.

Sternberg, R. J. (2012). The assessment of creativity: An investment-based approach. Creativity Research Journal, 24(1), 3-12.

Stierand, M., Dörfler, V. in MacBryde, J. (2014). Creativity and innovation in Houte cuisine: toward a systematic model. Creativity and Innovation Management, 23(1), $15-28$.

Zager Kocjan, G. (2016). Zavzetost, strast in zanos pri zaposlenih: Teoretična in empirična razmejitev (neobjavljena doktorska disertacija). Filozofska fakulteta Univerze v Ljubljani, Slovenija.

Zhang, L. in Sternberg, R. J. (2011). Revisiting the Investment theory of creativity. Creativity Research Journal, 23(3), 229-238. 


\section{Priloga}

Iz tabel 5 in 6 je razviden postopek prevajanja vprašalnika.

Tabela 5. Postopek prevoda imena Kaufmanovega vprašalnika ustvarjalnih področij in navodil

\begin{tabular}{|c|c|c|}
\hline & Izvirnik & Prevod \\
\hline naslov & Kaufman Domains of Creativity Scale (K-DOCS) & Kaufmanov vprašalnik ustvarjalnih področij \\
\hline navodila & $\begin{array}{l}\text { Instructions: Compared to people of approximately } \\
\text { your age and life experience, how creative would } \\
\text { you rate yourself for each of the following acts? For } \\
\text { acts that you have not specifically done, estimate } \\
\text { your creative potential based on your performance on } \\
\text { similar tasks. }\end{array}$ & $\begin{array}{l}\text { Navodila: Koliko ustvarjalni mislite, da ste, če bi } \\
\text { se morali za vsako izmed spodnjih dejanjih oceniti, } \\
\text { v primerjavi z ljudmi iste starosti in življenjskimi } \\
\text { izkušnjami. Pri tistih dejanjih, ki jih še dejansko niste } \\
\text { naredili, svoj ustvarjalni potencial ocenite glede na } \\
\text { izvedbo dejanj podobnih tem. }\end{array}$ \\
\hline & $\begin{array}{l}1 \text { - Much Less Creative } \\
2 \text { - Less Creative } \\
3 \text { - Neither More nor Less Creative } \\
4 \text { - More Creative } \\
5 \text { - Much More Creative }\end{array}$ & $\begin{array}{l}1 \text { - veliko manj ustvarjalen } \\
2 \text { - manj ustvarjalen } \\
3 \text { - niti manj, niti bolj ustvarjalen } \\
4 \text { - bolj ustvarjalen } \\
5 \text { - veliko bolj ustvarjalen }\end{array}$ \\
\hline
\end{tabular}

Tabela 6: Postopek prevoda Kaufmanovega vprašalnika ustvarjalnih področij

\begin{tabular}{|c|c|c|c|c|c|c|}
\hline št. & Izvirnik & Prevod 1 & Prevod 2 & Konsenz & Vzratni prevod & Popravki \\
\hline 1. & $\begin{array}{l}\text { Finding some- } \\
\text { thing fun to do } \\
\text { when I have no } \\
\text { money. }\end{array}$ & $\begin{array}{l}\text { Iskanje načinov } \\
\text { zabave, ko nimate } \\
\text { denarja. }\end{array}$ & $\begin{array}{l}\text { Znati se zabavati } \\
\text { brez denarja. }\end{array}$ & $\begin{array}{l}\text { Znati se zabavati, } \\
\text { ob pomanjkanju } \\
\text { denarja. }\end{array}$ & $\begin{array}{l}\text { To know how to } \\
\text { have fun despite } \\
\text { the lack of } \\
\text { money. }\end{array}$ & \\
\hline 2. & $\begin{array}{l}\text { Helping other } \\
\text { people cope with } \\
\text { a difficult situa- } \\
\text { tion. }\end{array}$ & $\begin{array}{l}\text { Pomoč drugim } \\
\text { pri spopadanju } \\
\text { s težkimi } \\
\text { situacijami. }\end{array}$ & $\begin{array}{l}\text { Pomoč drugim } \\
\text { pri spopadanju s } \\
\text { težko situacijo. }\end{array}$ & $\begin{array}{l}\text { Pomoč drugim } \\
\text { pri spopadanju } \\
\text { s težkimi } \\
\text { situacijami. }\end{array}$ & $\begin{array}{l}\text { Helping others } \\
\text { face difficult } \\
\text { situations. }\end{array}$ & \\
\hline 3. & $\begin{array}{l}\text { Teaching some- } \\
\text { one how to do } \\
\text { something. }\end{array}$ & $\begin{array}{l}\text { Učenje nekoga } \\
\text { drugega, kako } \\
\text { narediti nekaj. }\end{array}$ & $\begin{array}{l}\text { Naučiti nekoga } \\
\text { nekaj novega. }\end{array}$ & $\begin{array}{l}\text { Učenje nekoga } \\
\text { drugega, kako } \\
\text { nekaj narediti. }\end{array}$ & $\begin{array}{l}\text { Teaching others } \\
\text { how to do } \\
\text { something. }\end{array}$ & \\
\hline 4. & $\begin{array}{l}\text { Maintaining a } \\
\text { good balance } \\
\text { between my work } \\
\text { and my personal } \\
\text { life. }\end{array}$ & $\begin{array}{l}\text { Ohranjanje } \\
\text { stabilnega } \\
\text { ravnovesja } \\
\text { med delom } \\
\text { in zasebnim } \\
\text { življenjem. }\end{array}$ & $\begin{array}{l}\text { Uspešno } \\
\text { usklajevanje med } \\
\text { delom in osebnim } \\
\text { življenjem. }\end{array}$ & $\begin{array}{l}\text { Uspešno } \\
\text { usklajevanje med } \\
\text { delom in osebnim } \\
\text { življenjem. }\end{array}$ & $\begin{array}{l}\text { Successful } \\
\text { coordination } \\
\text { between work and } \\
\text { personal life. }\end{array}$ & \\
\hline 5. & $\begin{array}{l}\text { Understanding } \\
\text { how to make } \\
\text { myself happy. }\end{array}$ & $\begin{array}{l}\text { Razumevanje } \\
\text { kako se osrečiti. }\end{array}$ & $\begin{array}{l}\text { Vem kaj me } \\
\text { osreči. }\end{array}$ & $\begin{array}{l}\text { Razumeti, kaj me } \\
\text { osreči. }\end{array}$ & $\begin{array}{l}\text { To understand } \\
\text { what makes me } \\
\text { happy. }\end{array}$ & $\begin{array}{l}\text { Razumeti, kako } \\
\text { sam sebe osrečim. }\end{array}$ \\
\hline 6. & $\begin{array}{l}\text { Being able to } \\
\text { work through my } \\
\text { personal prob- } \\
\text { lems in a healthy } \\
\text { way. }\end{array}$ & $\begin{array}{l}\text { Sposobnost } \\
\text { reševanja } \\
\text { svojih osebnih } \\
\text { problemov na } \\
\text { zdrav način. }\end{array}$ & $\begin{array}{l}\text { Soočenje s } \\
\text { problemi na zdrav } \\
\text { način. }\end{array}$ & $\begin{array}{l}\text { Sposobnost } \\
\text { reševanja osebnih } \\
\text { problemov na } \\
\text { zdrav način. }\end{array}$ & $\begin{array}{l}\text { The ability of } \\
\text { solving problems } \\
\text { in a healthy } \\
\text { manner. }\end{array}$ & \\
\hline 7. & $\begin{array}{l}\text { Thinking of new } \\
\text { ways to help } \\
\text { people. }\end{array}$ & $\begin{array}{l}\text { Ustvarjanje novih } \\
\text { načinov pomoči } \\
\text { ljudem. }\end{array}$ & $\begin{array}{l}\text { Odkrivanje novih } \\
\text { načinov za pomoč } \\
\text { drugim. }\end{array}$ & $\begin{array}{l}\text { Odkrivanje novih } \\
\text { načinov pomoči } \\
\text { ljudem. }\end{array}$ & $\begin{array}{l}\text { To find new ways } \\
\text { of helping people. }\end{array}$ & \\
\hline 8. & $\begin{array}{l}\text { Choosing the } \\
\text { best solution to a } \\
\text { problem. }\end{array}$ & $\begin{array}{l}\text { Izbira najboljše } \\
\text { rešitve problema. }\end{array}$ & $\begin{array}{l}\text { Izbira najboljšo } \\
\text { rešitev problema. }\end{array}$ & $\begin{array}{l}\text { Izbira najboljše } \\
\text { rešitve problema. }\end{array}$ & $\begin{array}{l}\text { Choosing the best } \\
\text { solution to the } \\
\text { problem. }\end{array}$ & \\
\hline
\end{tabular}


9. Planning a trip or event with friends that meets everyone's needs.

10. Mediating a dispute or argument between two friends.

11. Getting people to feel relaxed and at ease.

12. Writing a nonfiction article for a newspaper, newsletter, or magazine.

13. Writing a letter to the editor.

14. Researching a topic using many different types of sources that may not be readily apparent.

15. Debating a controversial topic from my own perspective.

16. Responding to an issue in a contextappropriate way.

17. Gathering the best possible assortment of articles or papers to support a specific point of view.

18. Arguing a side in a debate that I do not personally agree

With.

19. Analyzing the themes in a good book.

20. Figuring out how to integrate critiques and suggestions while revising a work.

21. Being able to offer constructive feedback based on my own reading of a paper.
Načrtovanje izleta ali dogodka s prijatelji, ki vsem ugaja.

\section{Posredovati v nesoglasje med dvema \\ Posredovanje pri sporih med prijatelji.} prijateljema.

Pomagati ljudem, da se sprostijo.

Pisanje

strokovnega

članka za časopis, glasilo ali revijo.

Pisanje pisma uredniku.

Raziskovanje teme $\mathrm{z}$ uporabo številnih različnih virov, ki niso razvidni iz teme.

Razglabljanje o kontroverzni temi gledajoč s svoje perspektive.

Odzivanje na problem v skladu s kontekstom.

\section{Zbiranje}

najboljših

možnih člankov

ali poročil

za podporo

določenega

vidika.

Podpiranje

določene strani v

debati navkljub

nestrinjanju z njo.

Analiziranje tem

$\mathrm{v}$ dobri knjigi.

Ugotavljanje integracije kritik in predlogov med revizijo dela.

\section{Biti zmožen} ponuditi konstruktivno povratno informacijo na podlagi prebranega.
Načrtovanje izleta upoštevajoč interese vseh prijateljev.

Pripraviti ljudi, da se počutijo sproščeno.

Pisanje

strokovnega

članka za časopis, glasilo ali revijo.

Pisanje pisma uredniku.

Raziskovanje tem $\mathrm{z}$ uporabo različnih virov, ki niso neposredno razvidni.

Debatiranje o kontroverzni temi iz lastne perspektive.

Konstruktiven odziv na problem.

Izbrati najboljše članke, ki podpirajo določen zorni kot.

Argumentiranje strani v debati s katero se osebno ne strinjam.

Analiziranje tem v kakovostnih knjigah.

Ugotoviti kako integrirati kritike in predloge med pregledovanjem dela.

Zmožnost podati konstruktivno mnenje osnovano na lastnem branju članka.
Načrtovanje izleta ali dogodka ob upoštevanju interesov vseh prijateljev.

Posredovati

pri nesoglasju

med dvema

prijateljema.

Pomagati ljudem, da se sprostijo.

Pisanje

strokovnega

članka za časopis, glasilo ali revijo.

Pisanje pisma uredniku.

Raziskovanje teme $\mathrm{z}$ uporabo številnih različnih virov, ki niso neposredno razvidni.

Razpravljanje o kontroverzni temi z lastne perspektive.

Odzivanje na problem v skladu s kontekstom.

Izbrati najboljše

članke ali

poročila, ki

podpirajo določen

zorni kot.

Argumentiranje stališča v debati, $\mathrm{s}$ katerim se osebno ne strinjam.

Analiziranje tem v kakovostni knjigi.

Ugotoviti kako integrirati kritike in predloge med pregledovanjem dela.

Biti zmožen podati konstruktivno povratno informacijo na podlagi prebranega.
To plan a trip and to take all friends' interests into account.

To mediate with two friends' disagreement.

To help people relax.

To write a professional article for a newspaper, newsletter or a magazine.

To write a letter to the editor.

To explore a subject by using several different sources that are not directly evident.

To discuss a controversial theme from your own point of view.

To respond to a problem according to the context.

To choose the best articles or reports that support a certain point of view.

To argument a point of view in a debate that I personally disagree with.

To analyse the themes in a quality book. To find out how to integrate criticism and suggestions while reviewing the work.

To be able to give constructive feedback on what was read.
Pisanje

neumetnostnega

besedila za

časopis, glasilo ali revijo.
Analiziranje tem $\mathrm{v}$ dobri knjigi.

Ugotoviti kako integrirati kritike in predloge pri popravljanju dela 
22. Coming up with a new way to think about an old debate.

23. Writing a poem.

24. Making up lyrics to a funny song..

25. Making up rhymes

26. Composing an original song.

27. Learning how to play a musical instrument.

28. Shooting a fun video to air on YouTube.

29. Singing in harmony.

30. Spontaneously creating lyrics to a rap song.

31. Playing music in public.

32. Acting in a play.

33. Carving something out of wood or similar material.

34. Figuring out how to fix a frozen or buggy computer.

35. Writing a computer program

36. Solving math puzzles.

37. Taking apart machines and figuring out how they work.

38. Building something mechanical (like a robot).

39. Helping to carry out or design a scientific experiment.
Osmišljanje novega načina za razmišljanje o pretekli debati.

Pisanje pesmi.

Izmišljanje

besedila za

smešno pesem.

Ustvarjanje rim.

Komponiranje

lastne skladbe.

Učenje igranja

novega

instrumenta.

Snemanje

zabavnega filma

za YouTube.

Večglasno petje.

Spontano

izmišljanje

besedila rap

pesmi.

Igranje glasbe v

javnosti.

Igranje v dramski igri.

Tesanje iz lesa ali podobnega materiala.

Ugotavljanje

kako popraviti

računalnik, ki

zašteka ali ima

virus.

Pisanje

(kodiranje)

računalniškega

programa.

Reševanje

matematičnih

ugank.

Razstavljanje

naprav in ugotavljanje, kako delujejo.

Sestavljanje

mehaničnih

naprav (npr. robota).

Pomoč pri izvedbi ali dizajniranju znanstvenega eksperimenta.
Pogledati na staro razpravo iz nove perspektive.

Pisanje pesmi.

Pisanje zabavnih besedil pesmi.

Pisanje rim.

Komponiranje nove skladbe

Učenje igranja novega inštrumenta.

Snemanje

zabavnega videa

za objavo na

YouTubu.

Večglasno petje.

Spontano

izmišljanje

besedila za rap

pesem.

Igranje glasbe

pred občinstvom.

Igranje v

gledališki

predstavi.

Izrezovati nekaj

iz lesa ali drugih materialov.

Ugotavljati

kako popraviti

"zmrznjen"

ali "zaštekan"

računalnik.

Napisati

računalniški

program.

\section{Reševanje}

matematične

uganke.

Razstavljati

naprave in

ugotavljat kako

delujejo.

Zgraditi nekaj

mehaničnega (na

primer robot).

Pomagati pri

izvedbi ali

oblikovanju

eksperimenta.
Pogledati na staro To look at an old razpravo iz nove discussion from a perspektive. new perspective.

Pisanje pesmi. $\quad$ To write poems.

Pisanje zabavnih To write fun besedil pesmi. poetic lyrics.

Ustvarjanje rim. To make rhymes.

$\begin{array}{ll}\text { Skladanje } & \begin{array}{l}\text { To compose an } \\ \text { originalne }\end{array}\end{array}$

skladbe.

Učenje igranja To learn how novega to play a new inštrumenta. instrument.

Snemanje To make a fun

zabavnega videa YouTube video.

za objavo na

YouTubu.

Večglasno petje. To sing in

polyphony.

To make up a

rap song lyrics

spontaneously.

zmišljanje

besedila rap

pesmi.

Igranje glasbe $\mathrm{v} \quad$ To perform music

javnosti.

Igranje v

gledališki

predstavi.

Izrezljati nekaj

iz lesa ali drugih

materialov.

Ugotavljanje

kako popraviti

računalnik, ki

zašteka ali ima

virus.

Napisati

računalniški

program.

Reševanje matematičnih ugank.

in public.

To perform in a

theatre play.

To carve

something out of wood or other materials.

To know how

to fix a broken computer.

To write a computer program.

To solve mathematical puzzles.

Razstavljati naprave in ugotavljat kako delujejo.

Sestavljanje

mehaničnih

naprav (npr. robota).

To dismantle devices and to find out how they operate.

To assemble mechanical devices (e.g. a robot)

Pomoč pri izvedbi To assist in ali oblikovanju carrying out znanstvenega eksperimenta. or designing

a scientific

experiment. 
40. Solving an algebraic or geometric proof.

41. Constructing something out of metal, stone, or similar material.

42. Drawing a picture of something I've never actually seen (like an alien).

43. Sketching a person or object.

44. Doodling/drawing random or geometric designs.

45. Making a scrapbook page out of my photographs.

46. Taking a wellcomposed photograph using an interesting angle or approach.

47. Making a sculpture or piece of pottery.

48. Appreciating a beautiful painting.

49. Coming up with my own interpretation of a classic work of art.

50. Enjoying an art museum.
Reševanje algebrskega ali geometričnega dokaza.

Konstruiranje predmeta iz kovine, kamna ali podobnega materiala.

Risanje še ne videnega (npr. vesoljca).

Skiciranje osebe ali predmeta.

Čečkanje/risanje geometričnih oblik.

Delanje kolaža iz svojih fotografij.

Fotografiranje

dobre

kompozicije

$\mathrm{z}$ uporabo

zanimivega kota

ali pristopa.

Ustvarjanje kipa

iz gline.

Cenjenje lepe

slike.

Podajanje lastne interpretacije umetniškega klasičnega dela.

Uživanje v galeriji.

$\begin{array}{lll}\text { Reševanje } & \text { Reševanje } & \text { To solve an } \\ \text { algebrskih ali } & \text { algebrskega ali } & \text { algebraic or } \\ \text { geometričnih } & \text { geometričnega } & \text { geometric proof. }\end{array}$

dokazov.

dokaza.

Konstruirati nekaj

iz kovine, kamna

ali podobnega

materiala.

Narisati nekaj kar še nisi videl (na primer vesoljec).

Skiciranje osebe ali predmeta.

Čečkanje/risanje naključne ali geometrične vzorce.

Narediti kolaž iz svojih fotografij.

Narediti dobro

fotografijo

$\mathrm{z}$ uporabo

zanimivega

kota ali pristopa

fotografiranja.

Narediti skulpturo

ali lončeni

izdelek.

Ceniti lepo sliko.

Spomniti se lastne interpretacije

klasičnega

umetniškega dela.

Uživanje

v muzeju, umetnosti.
Konstruiranje predmeta iz kovine, kamna ali podobnega materiala.

Risanje česar še nisi videl (npr. vesoljca).

To construct an object of metal, stone or the like material.

To draw something one has never seen (e.g. an alien)

Skiciranje osebe ali predmeta.

To sketch a person or an object.

Čečkanje/risanje naključnega ali geometričnega vzorca.

Delanje kolaža iz To create a svojih fotografij. collage from your photos.

Fotografiranje To take a good dobre photo by using an kompozicije $\mathrm{z}$ uporabo zanimivega kota ali pristopa.

Ustvarjanje kipa ali lončenega izdelka. interesting angle or approach.

To make a statue or a pottery product.

To appreciate a beautiful painting.

Podajanje lastne interpretacije umetniškega To give your own interpretation of an artistic classical work To enjoy in a gallery.
Ceniti lepo sliko.
Narediti dobro

fotografijo

$\mathrm{z}$ uporabo

zanimivega

kota ali pristopa

fotografiranja. 